Journal of Community \& Applied Social Psychology

J. Community Appl. Soc. Psychol., 26: 47-60 (2016)

Published online 30 March 2015 in Wiley Online Library

(wileyonlinelibrary.com) DOI: 10.1002/casp.2234

\title{
No-man's Land: Adoption Storied Through the Aotearoa/New Zealand Adoption Act 1955
}

\author{
DENISE BLAKE* and LEIGH COOMBES \\ School of Psychology, Massey University, Wellington, New Zealand
}

\begin{abstract}
The Aotearoa/New Zealand Adoption Act 1955 legislated and governed adoption practices from 1955 to 1985 . Through an exploration of the historical, cultural and social assumptions underlying the Adoption Act 1955, this article questions how the social power relations complicit with adoption legislation and policy produce and reproduce subject positions for adoptees. In-depth narrative interviews were conducted with 12 adoptees from throughout Aotearoa/New Zealand. The researchers found the legal constitution of adoptees produces them as legitimate; however, they remain 'other' through dominant discourses of heteronormative blood kinship that reiterates their illegitimacy. The legal fiction of their legitimacy as if born to failed to secure them space within normative narratives of kinship and compromised adoptees' ability to take up responsibility as neoliberal citizens. Current New Zealand debate on adoption fails to take account of the experience of adoptees, focusing instead on the rights of married couples, including same-sex couples, to continue practices of adoption. Our analysis informs the critical importance of listening to how adoptees experience repeated exclusions and enduring loss represented by the metaphor of no-man's land. Copyright $(\odot) 2015$ John Wiley \& Sons, Ltd.
\end{abstract}

Key words: adoption; legitimacy; illegitimacy; rights; law reform

\section{INTRODUCTION}

Despite ongoing calls for the reformation of adoption law in Aotearoa/New Zealand, the Adoption Act 1955 continues to govern adoption practices. Since the inception of the Adoption Act 1955 it is estimated that 80000 adoption orders have been made, although Aotearoa/New Zealand does not officially record adoption data. In July 2012, Aotearoa/New Zealand's Prime Minister, John Key, stated 'realistically [adoption's] not the biggest issue that we face. I know it's important to those [same-sex] people, but they're a very small group' (3 News, 2012, para 6). The context of Key's statement is related to

*Correspondence to: Denise Blake, School of Psychology, Massey University, Wellington, New Zealand. E-mail: d.blake@massey.ac.nz 
issues of equality in legal marriage and a non-discriminatory right to adopt. The Marriage (Definition of Marriage) Amendment Act 2013 that took effect on 19 August 2013 enabled same-sex couples to marry, therefore opening up space for contesting the exclusivity of heterosexual marriage within the Adoption Act 1955 (Ludbrook \& Else, 2012, August; The Department of Internal Affairs: Te Tari Taiwhenua, 2014). While the current debates remain focused on the right to adopt, the effects of adoption legislation on adoptees and their birth and adoptive families continue to be ignored. It is the ongoing failure of the state to recognise the social injustice of the Adoption Act 1955 that law reform advocates argue is an abuse of power (Griffith, 1991; Henaghan, 2006; Ludbrook, 1997). The claim that adoption is not a big issue goes against the review by the Aotearoa/New Zealand Law Commission: Te Aka Matua O Te Ture (2000) that found the current law breaches international standards for the best interests of children, and their relationships with their family of origin. The report recommends a legal framework that accounts for socio-political changes to the diverse forms of relationships that constitute contemporary families, such as same-sex couples, and the advances in reproductive technologies that shift the boundaries of heterosexual marriage.

At the same time, the Australian Government conceded its discriminatory adoption practices by offering an apology and compensation to unwed mothers for their immeasurable suffering, as they were coerced, bullied and terrorised into relinquishing their babies from the 1940s onward. Within the contemporary geopolitical landscape of Australia, there has emerged a climate of apology that sought to redress the abuses of government policies that produced what is known as the 'stolen generation' of aboriginal children and the national shame of breaches of indigenous rights (Cuthbert \& Quartly, 2013; Murphy, Quartly, \& Cuthbert, 2009). By 2012, inquiries into the removal and mistreatment of children had extended into the culturally and legally constituted governance of the forced removal of children for adoption and led to the inclusion of adoptees and their birth mothers into 'the space of national apology and regret in Australia' (Cuthbert \& Quartly, 2013, p. 179).

Fronek and Cuthbert (2013) problematise the rhetoric of apology through its reference to 'past' harmful and unacceptable practices that necessitate regret through the complicating increase in 'present' practices of intercountry adoption. They argue that intercountry adoption practices are embedded in this history in the present; practices apologised for in the domestic space persist in intercountry adoptions. Therefore, Fronek and Cuthbert question the lesser standards that are tolerated for children and their birth mothers. Where birth mothers of domestic adoptions were included in the rhetoric of apology, the shift to intercountry adoptions is framed as humanitarian action in the service for infertility, and as a legitimate response to children in need, reproducing birth mothers as invisible.

At the same time that the Australian government was apologising for past abuses, there has emerged an 'unashamedly pro-adoption discursive space' (Murphy et al., 2009, p. 204) that appropriates the call of the adoption reform movement's claims in the 'best interests of the child'. In such space, it is argued that adoption may be more effective as a permanent solution to the problems of foster and out-of-home care for Australian children. Based on the contemporary socio-legal presumption of the best interests of the child to maintain family and cultural connections, adoption is promoted as an intervention to ensure stability. This same logic permeates post-separation parenting relationships in current family court decisions in Australia and New Zealand (Elizabeth, Tolmie, \& Gavey, 2011).

In Aotearoa, Justice Minister Judith Collins responded to questions about an apology, here, by claiming that the government 'had no official part in influencing mothers to give 
up their babies' (One News, 2012, para 4). This article traces the history of the governance of adoption practices in Aotearoa/New Zealand before considering how a narrative inquiry into the subject positioning of adoptees supports calls for legislative reform and recognition of the implications of the Adoption Act 1955 for those subjected to its legal force.

\section{SOCIO-POLITICAL HISTORY}

In Aotearoa/New Zealand's history, legislative policies are constituted through economic, social and moral discourse that enable and constrain specific subject positions within a particular set of social power relations of domination and subordination. The institution of adoption can be understood as a technology of power that governs women's sexuality and reproduction and regulates the maternal body through a Eurocentric patriarchal moral order, where the British colonial common law concept of nullius filius (the child of no man) governed the boundaries of legitimate and illegitimate subjects. The legal constitution of the child of no man produced the illegitimate subject with no rights to inheritance of property, name or economic support; they were excluded from a birthright (Griffith, 1997; Van Doren, 1916). Legitimacy and inheritability in the name of the father were proscribed culturally, legally and morally. The illegitimate child became the subject of risk to public morality and a burden to the state (Carp, 2009; Delany, 1997; Kohli, 2003).

The movement towards the legislation of adoption in Aotearoa/New Zealand is specific to its history of colonial power. Prior to the legislation of child welfare practices, illegitimate children were subject to an indenturing system of labour. Settlers sought claims to an abundance of 'uninhabited' land, and the indentured labour of illegitimate children functioned as a crude means of adoption. Illegitimate children were taken from state poor houses and enslaved to work for their keep, relieving the economic burden on the state (Iwanek, 1997; Triseliotis, Shireman, \& Hundleby, 1997). As the orphanage movement emerged during the mid-1880s alongside a concern for high child mortality rates, a system of financial incentives for fostering illegitimate children enabled the development of a process akin to adoption (Carp, 2009; Triseliotis et al., 1997). Fostering was premised on the assumption that such placements would be in the best interests of the children, although it did not address issues of illegitimacy, or enslavement. The first legislated adoption act of the British Empire, the New Zealand Adoption Act 1881, had at its core the protection of adoptees and economic benefit to the state. However, issues of legitimacy remained, especially where inheritance depended on the marital status of parents (Griffith, 1991). Of significance in this early legislation was the inheritance of birth names, often hyphenated with adoptive names (Griffith, 1997). However, land heritability was contested. The Adoption Act 1881 did not legally impinge on Māori customary practices of whangai (a child raised within the kinship system), but the 'insidious eroding of the whangai system' through colonialist regulation of Māori was enacted through the subsequent Native Land Claims and Adjustment and Amendment Act 1901, and the Native Land Act 1909 (McRae \& Nikora, 2006, p. 1). Adoption legislation began a process of severing whangai practices of kinship and authorised adoption practices that were no longer kinship-based. Adoption law was embedded in property law and constituted the adopted child as a commodity (Ludbrook, 1997).

By 1915, through the Births and Deaths Registration Amendment Act 1915, Aotearoa/New Zealand became the first country in the world to authorise birth certificates in the name of the adoptive parents (Carp, 2009). The legislation sought to protect 
adoptees from living the stigma of illegitimacy; however, severing a child's birth identity and their relationship with their heritage is an act of cultural violence that served to protect the identity of the settlers (Bradley, 1997; Griffith, 1997; McRae \& Nikora, 2006).

The early legislative movements culminated in the Adoption Act 1955 that constituted adoptees as if born to their adoptive parents who are granted control over rights of succession. The severing of birth relationships realised a 'complete break', where sealing birth records constructed a wall of secrecy, closing off the possibility for an ongoing blood-kin relationship. In this way, the adoptee is cut from their birth connections (Griffith, 1991; Simmonds, 2000) and required to relinquish all claims to her/his birth identity, as if it was a threat to their well-being (McRae \& Nikora, 2006). The act instituted 'closed adoption'.

Excluding blood-kin relationships was justified through the gendered moral positioning of the birth mother. The practice of secrecy was important to 'protect' the birth mother and her family from the shame of her weak moral character (Gediman \& Brown, 1991; Murphy et al., 2009). The complete break strategy was maintained through the social power relations that constitute women's sexuality and reproduction as uncontrollable (Bartky, 1988; Cuthbert, Murphy, \& Quartly, 2009; Cuthbert \& Quartly, 2013; Kitzinger, 1992; Sawicki, 1999; Ussher, 1997). Mothers of illegitimate children were 'fallen' women who were unable to be contained within bodily contradictions: maternal and evil, weak and powerful. Two maternal bodies are implicated; the immoral birth mother and the infertile woman link the meaning of women to body (March, 1995; Wegar, 2000), and neither escapes the shameful effects of an out-of-control body.

In effect, the Adoption Act 1955 created a legal fiction for adoptees. Fiction in law is a supposition that contradicts fact, traditionally accepted because it has practical implications. In this case, the fiction constituted a legitimate identity for adoptees in contradiction to their illegitimacy (Griffith, 1991; Ludbrook, 2008). Within the act, 'as if' constructed the fiction: Section 16(2)a of the Adoption Act (1955) grants legitimacy 'as if the child had been born to that [adopting] parent in lawful wedlock'. In this way, the biological and embodied fact of birth relationships is replaced with the condition of institutional (heterosexual) marriage as the legitimating story.

Since the inception of the Adoption Act 1955, those it has subjected have lobbied against legislation that coerced birth mothers to relinquish their children and denied those children access to their birth origins (Griffith, 1997). Māori advocated for whangai practices to be privileged, not only recognised (McRae \& Nikora, 2006), and alongside research on the benefits of connections to birth families (Bradley, 1997), the Aotearoa/New Zealand Government passed the Adult Adoption Information Act 1985. This was a step towards resolving the issues of a 'complete break' by allowing adoptees to access their original birth certificates, opening up the possibility for identifying birth mothers and making contact with them (Griffith, 1997). Access to birth information can be limited through veto provisions that maintain complete severance and reinforce secrecy. Around the same time as the passing of the Adult Adoption Information Act 1985, social workers and advocates led a shift in adoption practices that enabled contact and open communication between birth and adoptive parents. However, practices of 'open adoption' are not recognised in law, and control over the relationship remains with the adoptive parents. While 'open' adoption practices might value blood kinship, legislation continues to delegitimise relationships with birth families and the Māori practice of whangai (McRae $\&$ Nikora, 2006). The failure of the government to address the legislative abuse of mothers and children that severs their relationship is a significant social and moral issue for 
adoptees and their advocates. The movement for adoption law reform continues to challenge the exclusion of adoptees from their social and cultural histories.

In the following sections, we present research with adoptees that was conducted as part of a larger study investigating how adoptees' narratives of their lived experience testify to their legal exclusion from normalising kinship narratives, which constitutes psychosocial responses that are observed as abnormalities and result in their over-representation in clinical populations. Analysis from the larger study, contextualised by the history of governing adoption practices in Aotearoa/New Zealand, is engaged in this paper to show how adoptees negotiations of their positioning within narratives that are legitimated in law support the call for legislative reform.

\section{PRESENT STUDY}

Prior to selecting participants, the ethical protocol of the larger study was approved by the Massey University Ethics Committee.

\section{Participants}

A purposeful sampling technique was used to locate 12 participants through the social networks of the first author. The criterion for participation was the experience of 'closed' adoption. Three men and nine women, aged 26-52 years and representing nearly three decades of the practice of closed adoption (1955-1985), agreed to take part in a conversational interview that made explicit the researcher's interest in the ongoing impact of the act on the experiences of adoptees.

The participants' experiences of access to their birth families were diverse, although all but two have had birth family contact. The birth mother vetoed contact for one, while the other was unable to find any birth mother information. Two of the participants were contacted by birth families while growing up; the other eight did not have birth family contact until they were adults. One participant identified as Māori, while two had knowledge of Māori blood kin. For all, genealogical kinship remained problematic, embedded in complex life histories. Birth mother contact had been lost for one participant who was subsequently unable to pursue blood-kin relationships. Another participant was denied access to her patrilineal Māori connections, and another did not have success in tracing any patrilineal genealogy at the time of the interview.

The participants' narratives were textured by race, ethnicity, culture and socio-economic status. Adoptive family structures were also diverse and included divorced and one-parent families, adopted siblings and siblings born to adoptive parents. There was diversity among participants in how they described their adoptive families: loving, normal, abusive, dysfunctional and so on. Their diversity was not static, and their relationships with particular events unfold as a process, constituting ongoing psychosocial effects in their lives, and the lives of their families.

\section{Data collection}

Participants took part in one to one interviews, conducted in a conversational style, with the first author. The interviews were co-productions of adoptees' stories, which were led 
by the participant so that they could tell their personal narratives in ways that were meaningful to them, within a context where their voices were honoured. Interviews lasting between 1 and 2 hours were digitally recorded. They were transcribed verbatim with notations marking non-verbal interactions, pauses, sighs and hesitations. Participants were given the opportunity to read and review the transcription of their interviews and to provide permission to use their stories to illustrate the analysis.

\section{Analytic process}

Transcripts were read and re-read for tone, imagery and the ordering of life events as a starting point for analysis. Because the narrative tone organises the 'feel' of the storyline, and imagery is used to make sense and embody a narrative pattern (McAdams, 1993), these analytic devises were used to organise stories and identify subject positions available as adoptees told of their lived experiences. Those experiences that are not always accessible through every day talk - the silenced stories told through hesitation and feeling — were also identified during the analytic process.

The analysis then involved re-structuring the interview transcripts to focus on the ways in which the adoptees produced their narrative identities: the metaphors, the storylines and the embodied moments that were recognised between the researcher and participants in the telling (Polkinghorne, 2005; Riessman, 2008). In relation to the present study, the metaphors, storylines and embodied moments that informed participants' engagement with law reform have been represented as a hybrid narrative of living the effects of their constitution through a legal fiction.

\section{ANALYSIS}

\section{The fiction of legitimacy}

The Adoption Act 1955 provided the conditions for an illegitimate subject to be made legitimate. The meaning of legitimacy was contested by the participants through their recognition of a space that marked the boundaries between illegitimate and legitimate. Space, in this sense, is "where social relations are produced and reproduced as texts, where the signs and symbols, stories and meanings of connectedness and exclusion become sites of contestation' (Coombes \& Morgan, 2015, p. 444). Language is implicated in the relationship between people and institutions that enacts power relations.

The participants spoke of a space, a gap, a void and a suspension in time that positioned them without biological connection or legitimate sanction. In their telling, they embodied a moment of time, a breath and an awareness of an in-between space that was experienced as 'too big to comprehend' (Barry).

As I got older, I did think about the illegitimate side of it, you know when you suddenly become aware that children are born out of wedlock...I remember thinking that there had to be a time, like when you are born and when you are adopted when you are in no-man's land. (Mary)

To be born nullius filius positions a child in no-man's land, neither born to nor as if born to. The metaphor of no-man's land signifies the space between two conflicting forces, a place where no one is safe. The association of no-man's land with the child's location at the very moment she/he is suspended between birth family and adopted family evokes 
the image of a conflict requiring moral resolution. In no-man's land, the child is unsafe without the protection of their adoptive parents' marriage. In the contest over legitimacy, the territory represents an erasure of a birth identity.

It was important for participants to know the time they were in-between, and this varied across accounts from 10 days to 6 months. The time spent in no-man's land structured the participants' narrative identity, where the embodiment of their illegitimacy was told as a lack of affection and connection, reinforcing their position in the barren place of noman's land.

It's important to me to know how long I was in that adoption hospital...you know, alone. (Brendon)

Not having your mother there to pick you up and cuddle you every time, 'cause a nurse can't give 24 hour care. (Mary)

The time in-between was meaningful to how adoptees understand their lack in social and cultural narratives of legitimacy. Their narrative identities were formed through an understanding of their location at the intersection of no-man's land and legitimacy at a personal level, through stories that connected meanings of illegitimacy with their sense of themselves: not good enough.

I wasn't good enough...I think you'll be judged...that you are nobody. (Vaughn)

My umm shame, embarrassment, I don't know how I was conceived...mistake, that's how I thought of myself-a mistake. (Toni)

You know there is something fundamentally wrong with this 'me' baby, that wasn't wanted. (Maxine)

Constituted through the legal resolution of a moral conflict, adoptees legitimacy was experienced as precarious. Even where legitimacy is enabled through legal discourse, the social and cultural implications of being born illegitimate remain. The legal fiction of legitimacy fails to rectify the stigma of illegitimacy and its process of dehumanisation.

The shame and isolation of illegitimacy and the burden of lack were reproduced through narratives of adoption that normalised adoptive families. Commonly told narratives to account for adoptees' difference positioned them as holding special status because they were chosen.

She (adoptive mother) would pretend to get on the phone to Social Welfare and tell them to take us back... [or she was] going to sell us for a bag of rice and we believed it...so there was always this threat that we would be like, she chose to have us she could also choose to get rid of us. (Jan)

Within this storyline, the meaning of being chosen is the very possibility of being revealed as illegitimate. Legitimacy is only tentative, and as argued by Griffith (1991), knowing you have been relinquished by one (birth) parent makes the possibility of it happening again very real, signifying a return to no-man's land.

Positioned as if born to did not protect the participants from living the effects of their moral deficit when the taken-for-granted assumptions that socially and culturally determine legitimacy is blood kinship. The kinship produced through adoption legislation cannot replicate the sociocultural meanings of biological family relationships. In the production of their narrative identity, adoptees lack the language of blood, biology, roots, heritability and other sociocultural markers that connect people to their genealogy in meaningful ways. 
Adoptees embody the differences in meaning as the 'other' of normalised 'proper' blood kinship, repeatedly (re)positioned through their illegitimacy within family relationships. As if born to is not the same as born to among siblings, the position of the bastard child of no man reproduced through social power relations were painful reminders of adoptees' exclusion.

They knew if they wanted to hurt me when I was a kid they'd say 'you're a bastard because you're born out of wedlock' ... and you know... that shit used to hurt-labels like that... would cut me up but like the only one was my little sister who would say, 'you're not my brother, fuck you, you're not my brother'. (Brendon)

Through this storyline, legitimacy did not protect from but rather reinforced the effects of difference. The meaning of difference was storied through sociocultural norms of blood kinship. All participants understood their positioning outside sociocultural meanings of 'family' (re)reproduced through experiences of family tree exercises in schools, where they could not identify themselves with familial roots. The dominant narrative of blood kinship that produces ancestral branches challenged the authenticity of adoptees' identities, revealing the legal fiction of their legitimacy.

The lived experience of being born to and as if born to is located on the boundaries between the biological and sociocultural realities of the adopted family (Triseliotis et al., 1997). Where blood kinship is privileged, the meaning of relationships constituted through legal fiction is contested.

How can you be not blood related but still have that link? (Toni)

While as if born to produces a moral subject entitled to the benefits of the name of the father, it did not provide protection from their positioning outside taken-for-granted assumptions of blood kinship as the marker of authenticity. The fiction was unable to sever the participants' embodied knowledge of their birth history, or the moral force of illegitimacy that produced their narrative identities. Despite their positioning as legitimate, the participants told their difference as not belonging; feeling alone, there being no one that is the same. '[There is] no one I could rely on but me' (Margaret). In this sense, without reshaping their narrative identity to 'fit', adoptees remained outside authentic kin membership. Metaphorically, fitting a square peg into a round hole describes the idiomatic position of not being able to fit into place, where place marks a relationship of belonging and continuity that is dependent on genealogical connections to ancestral and living communities in Aotearoa/New Zealand (Nikora, Awekotuku, \& Tamanui, 2013).

I feel like a waif and stray (laugh)...I've often felt like I haven't fitted in and not belonged. That fitting in is a really big thing. (Maxine)

I certainly had a rough time as far as, never felt like I quite fitted in, umm home was awful, hated being there. (Margaret)

I didn't fit in anywhere...I'm always in the middle and it's just like, it's not a very nice place to be, it wasn't a very nice place to grow up. (Alice)

The metaphor of 'fit' indexes a sense of belonging that is authorised through blood kinship, and the lack of fit was embodied by the participants through feelings of intense and lasting aloneness. These experiences resonate with Hoksbergen's (1997) notion of adoptees' psychic homelessness, where their location in-between has an unstable foundation, a rootlessness. In the production of their narrative identity, adoptees recognised their 
difference from their adoptive family, and that difference was embodied as unnatural and disconnected.

I think as an adoptive person you don't have, I mean I feel like I have a forced relationship with my family [adoptive]. It doesn't come natural... we don't have that same click...we're just different, you know, so I don't feel like I've ever really had that connection and still don't and probably do more out of, I probably, like I go down and see her and I take her out and I do this 'cause she's 78 now, more out of, and I shouldn't say obligation 'cause that's really horrible, but it probably is out of that. (Sally)

It was hard growing up with mum because she was so different... and I got how different she was when I met my birth mother; it's just like 'fuck'?! (Brendon)

I still find it hard to be close with them, I mean I'm close to them but it's not like, it doesn't just flow you know. It feels so, umm friction, bit of friction probably more from me yeah, $\mathrm{mmm}$. (Maxine)

That most of the participants experienced themselves as different from rather than belonging to their adoptive family mirrors early research findings where three out of four adoptees reported a lack of closeness and belonging to their adoptive family (Triseliotis, 1973). The fiction of as if born to left participants ill-fitting their legitimacy, reproducing them in the space outside normative narratives of kinship. Located on the borders of legitimacy and illegitimacy produced difference and disconnection from adoptive families and also marked a site of conflict between adoptees and their birth families. Within the complexities of the violent break from blood-kin connection, reunions with birth families can also reproduce the disconnection.

They [birth family] just can't deal with it, they kind of all believe like I have my own family and you know I have my own life and yeah, it's nice to have, umm, it's nice that I'm in their lives, arrh particularly for my birth mother, and so I think there's a lot of respect there for her and their relationship with her...so they're by proxy with me, but I really get that umm, it's not with me. (Barry)

Psychic homelessness can be understood through spaces adoptees inhabit in social power relations. In the production of their narrative identities, the binary coordinates of legitimacy/illegitimacy, authentic/fictional and connected/severed are reconfigured into exclusions that mark the borders of no-man's land. Blood kinship becomes the space where stories and meanings of connectedness and exclusion are contested. The fiction as if born to is implicated in ongoing contests over the meaning of kinship, where neither adoptive nor birth families entitle adoptees to normative kinship. As if born to severs connection: 'I'll never be anybody's biological child' (Maxine). The legislated family connection does not relieve adoptees of the burden of illegitimacy and does not heal the violence of the cut from their genealogy.

\section{Voice, authenticity and resistance-a call for law reform}

Despite the lack of social and political acknowledgement of the significance of law reform for adoptees, advocates continue to challenge the moral authority of the legal fiction as if born to. That the government considers the calls for change to be of little political significance enacts ongoing structural violence (Henaghan, 2006) for those more than 80000 citizens subjected to its power. All of the participants in this study recognised the moment and the process of their interpellation into the voiceless space of no-man's land as marking 
the boundaries of blood kinship and authorising authentic relationships of belonging within the continuity of blood-kin connections. While the Adult Adoption Information Act 1985 recognised the value of kinship connection, in effect, it only provided the mechanism for opening up the possibility of identifying birth mothers and potential contact in adulthood. Without changes to the Adoption Act, the Adult Information Act was already limited and limiting. All of the participants talked about the complexities of their lack of knowledge of their birth kin through their ignorance of health indicators that are increasingly necessary for neoliberal subjects to become responsible citizens. Access to biological and genealogical knowledge was understood as a human right among the participants.

I think it should change, but I think that if, for whatever reasons the parents and the birth mother feel that in their situation a closed adoption would be better, I think that should be able to happen... but I think that when the adoptee turns 21 or whatever they should have the right to information then and I think that through, all the way through, they should be able to have access to medical records and some sort of umm, sort of knowledge about their roots. (Shelly)

Where technological advances into health and risk require good (legitimate) citizens to know their biological history and act to achieve good health outcomes, adoptees are excluded from participating in the health practices of good citizenship. Located within a context where technologies of reproduction regulate risky reproductive bodies (Ussher, 2010), adoptees remain positioned as commodities for the disciplining of women's morality and as an intervention into infertility, well into their adulthood. The authority to speak is legitimated through social power relations that uphold the moral order and silence the voice, and the best interests, of the adoptee.

You know until we get some politician...with a lot of political savvy, then why would anyone care...I actually think it's even worse than that, which makes me a bit despondent, but if we look at the dialogue I guess on umm reproductive technologies...I find that just so offensive, and yet again what it shows about society is that adoption, which I guess is a form of reproductive technology for infertile parents, is that it's parent focused, adult focused...none of that dialogue is around the kids, rights lie with parents, with adults...not with the kids. (Barry)

The exclusion of the voice of the adoptees from political dialogue on their best interests reproduces the structural violence enacted through the Adoption Act 1955, in that it 'contains no reference to the child's rights - its focus is predominantly on the two sets of parents' (Ludbrook, 2008, para 2). Positioning in no-man's land is repeated; as the participants embodied their lack of connection to dominant narratives of blood kin, they recognised these same relationships in the government's failure to acknowledge the harm of the oppressive and discriminatory practices authorised through the act. The participants embodied the space of their relationship with the law as another form of intimate exclusion, suspended in time without connection, in a globalised economy in which they are rendered invisible.

Well there just seems to be so much more that's more important, you know what I mean, like the government and their little people fucken losing their jobs and what's happening overseas and all that stuff, you know, it's certainly not, I don't see it on their list of important things. (Cooley)

Because adoptees embody their exclusion from normative kinship through stories that form their sense of not being 'good enough', the unwillingness of governments to acknowledge the effects of Adoption Act 1955 reiterated their sense of inadequacy: other subjects, other issues and other problems are seemingly always more significant than them. 
The participants were positioned outside narratives of legitimate citizens in a gendered social power relationship that is a repetition of their legitimacy depending on a paternal relationship. Political inaction by the government was understood by the participants as authorising and regulating the boundaries of legitimacy through a patriarchal moral order that has enabled politicians to walk away from recognising the effects of closed adoption.

I think umm, it's a female thing and males aren't interested in that...so how can a male that's sitting in a politician's, sitting in government, be interested...because men walk away all the time. (Sally)

The lack of political significance to warrant the attention of the government and the failure of the government to recognise the suffering legislated and enacted through regulated policy reproduce exclusion. The fiction of legitimacy marks the boundary of normalisation and regulates the technologies that divide and categorise adoptees within heteronormative narratives of kinship. The legitimacy of adoption refuses adoptees the specificity of a category within the population; they are subjected to the same cultural narratives of individualism repeated through neoliberal forms of governmentality that effectively discard them as authentic citizens.

[There is no law reform] because it's boring and...people who are adopted are part of that disposable population that people don't care about...there's not a huge moral, 'cause well, as the adoption's happened. There's stuff about sex outside of marriage, or being able to look after children, or abuse of children has been dealt with so there's actually, with the adoption thing itself, there's no huge dramas directly related to it. You can't, it's probably more difficult to get people's moralistic anger up about it...so you won't get, I don't think in public world, I don't think you'll get two hugely heated sides to the debate that then make an agreement happen in the middle... so the debate isn't going to be loud...the pro's and con's will just be umms and arrhs...'cause it's not quite, and it's only emotive for people who see that they have been directly harmed by it. (Jan)

\section{CONCLUSION}

The socio-political narrative traced through the history of the governance of adoption practices in Aotearoa/New Zealand specifies the social power relations of the government's 'official influence' in the subjugation of adoptees and their birthmothers is evidenced through the analysis. The metaphor of no-man's land as a space of exclusion has the potential for transformative action that recognises the implications of the Adoption Act 1955.

This paper set out to inform current debates on adoption law reform by setting adoptees' stories of their life experience within the context of the history of governing adoption in Aotearoa/New Zealand. We traced the historical trajectory of governing the lives of illegitimate, abandoned or orphaned children as it moved from the indentured labour systems to the effects of the secrecy of closed adoption that is the focus of the contemporary reform movement. This history testifies to how the government of Aotearoa/New Zealand has been increasingly relieved of the burden of responsibility for the moral, social and political consequences of past legislative practice in the contemporary lived experience of adult adopted children.

The Adoption Act 1955 sought to ameliorate the social and moral consequences of illegitimacy through the creation of a legal fiction that children born out of wedlock were legitimated by their adoptive families. For adoptees, this fiction produced a space metaphorised as no-man's land: an in-between of blood kin and legal kin, illegitimacy 
and legitimacy. No-man's land is unsafe, disconnected from normalised relations of kinship, characterised by the shame of illegitimacy and compromised identities. The Adoption Act 1955 failed to redress the stigma of illegitimacy with often life-long consequences for adoptees' well-being.

The current government of Aotearoa/New Zealand, in power since 2008, has steadfastly refused to consider accepting responsibility for the consequences of adoption legislation. The debates, which have brought government responsibility to attention, have focused on the rights of same-sex married couples to adopt and the apology made by the Australian government to adoptees and their birth mothers. In neither case have the voices of adoptees calling for legislative reform been included within the debates. Arguably, the apology made by the Australian government did respond to the voices and experiences of adoptees, birth mothers, families and tribes, beginning with the activism of indigenous people for the recognition of their stolen generations. Despite the disruptions and damages of the Adoption Act 1955 to indigenous practices of whangai, to whanau, iwi, hapu and generations of adopted Māori children, there has been no such recognition in Aotearoa/New Zealand. While the Australian government's apology has not gone far enough to redress the wrongs of the past (Fronek \& Cuthbert, 2013), a space has opened there for debate on the measures that would be needed to begin processes of reconciliation and healing. The government of Aotearoa/New Zealand has refused to engage with their responsibility for facilitating similar opportunities here.

The Australian literature also speaks to debates in contemporary discourse on intercountry adoption practices. In this debate, adopted children occupy positions as the subjects of humanitarian concern who fulfil adoptive parents' needs for heteronormative generative kinship. The legal notion of the 'best interests of the child' is foregrounded without attention to the responsibilities of government for the harms of adoption as a technology of social dislocation. Our analysis demonstrates the complexity and endurance of harms generated through the separation and dislocation experienced by adoptees who live the legal fiction of adoptive legitimacy. How much more complex, and how enduring, the harms of intercountry adoptive practices might be is rarely considered in the context of prioritised humanitarian need.

Taking account of the harms consequent to adoption practices of the past could lead to more transformative possibilities in contemporary debates. Opening space for listening through the metaphor of 'no-man's land' to the exclusions adoptees experience expand the horizons of possibility for redressing past wrongs, not only through apology, but through transforming contemporary social, legal and political consequences of adoption towards more just and safer futures.

\section{REFERENCES}

Adoption Act. (1955). Adoption Act 1955 s93 [Electronic Version]. Retrieved from http://www.legislation.govt.nz/act/public/1955/0093/latest/DLM292661.html [Access date: 10th March 2009]

Bartky, S. L. (1988). Foucault, femininity, and the modernization of patriarchal power. In I. Diamond, \& L. Quimby (Eds.), Feminism and Foucault: Reflections on resistance (pp. 61-81). Boston, MA: Northeastern University Press.

Bradley, J. (1997). Kei konei tonu matou (We are still here). In New Zealand Adoption Education and Healing Trust (Ed.), International Conference on Adoption and Healing (pp. 37-44). Wellington, New Zealand: New Zealand Adoption Education and Healing Trust. 
Carp, E. W. (2009). How tight was the seal? A reappraisal of adoption records in the United States, England and New Zealand, 1851-1955. In G. M. Wrobel, \& E. Neil (Eds.), International advances in adoption research for practice (pp. 18-39). Oxford, England: Wiley-Blackwell.

Coombes, L., \& Morgan, M. (2015). South Pacific: Tensions of space in our place. In I. Parker (Ed.), Handbook of critical psychology (pp. 444-453). New York: Routledge.

Cuthbert, D., Murphy, K., \& Quartly, M. (2009). Adoption and feminism: Towards framing a feminist response to contemporary developments in adoption. Australian Feminist Studies, 24, 395-419. doi: 10.1080/08164640903289302

Cuthbert, D., \& Quartly, M. (2013). Forced child removal and the politics of national apologies in Australia. The American Indian Quarterly, 37(2), 178.

Delany, D. (1997). Understanding adoption: Epistemological implications. In New Zealand Adoption Education and Healing Trust (Ed.), International Conference on Adoption and Healing (pp. 115-129). Wellington, New Zealand: New Zealand Adoption Education and Healing Trust.

Elizabeth, V., Tolmie, J., \& Gavey, N. (2011). Gendered dynamics in family court counselling. New Zealand Journal of Counselling, 31, 1-20.

Fronek, P., \& Cuthbert, D. (2013). Apologies for forced adoptions practices: Implications for contemporary intercountry adoption. Australian Social Work, 66, 402-414. doi: 10.1080/ 0312407X.2013.777970

Gediman, J. S., \& Brown, L. P. (1991). Birthbond: Reunions between birthparents and adoptees what happens after. Fars Hill, NJ: New Horizon Press.

Griffith, K. (1991). The right to know who you are: Reform of adoption law with honesty, openness and integrity. Toronto, Canada: Katherine W. Kimbell.

Griffith, K. (1997). The legal and social history of adoption in New Zealand. In New Zealand Adoption Education and Healing Trust (Ed.), International Conference on Adoption and Healing (pp. 45-49). Wellington, New Zealand: New Zealand Adoption Education and Healing Trust.

Henaghan, M. (2006). Adoption - time for changes. New Zealand Family Law Journal, 5, 131-134. Retrieved from http://www.lexisnexis.co.nz/products/products-by-name/family.aspx

Hoksbergen, R. (1997). The adoption field is full of pitfalls for professionals. In New Zealand Adoption Education and Healing Trust (Ed.), International Conference on Adoption and Healing (pp. 21-31). Wellington, New Zealand: New Zealand Adoption Education and Healing Trust.

Iwanek, M. (1997). Adoption in New Zealand - past, present and future. In New Zealand Adoption Education and Healing Trust (Ed.), International Conference on Adoption and Healing (pp. 62-73). Wellington, New Zealand: New Zealand Adoption Education and Healing Trust.

Kitzinger, S. (1992). Ourselves as mothers: The universal experience of motherhood. London, England: Doubleday.

Kohli, H. D. (2003). Law and illegitimate child: From Sastrik Law to Statutory Law. New Delhi, India: Anmol.

Law Commission: Te Aka Matua O Te Ture. (2000). Report 65. Adoption and its alternatives: A different approach and a new framework. Wellington, New Zealand: Law Commission: Te Aka Matua O Te Ture.

Ludbrook, R. (1997). Closing the wound. An argument of the abolition of adoption. In New Zealand Adoption Education and Healing Trust (Ed.), International Conference on Adoption and Healing (pp. 57-60). Wellington, New Zealand: New Zealand Adoption Education and Healing Trust.

Ludbrook, R. (2008). Adoption law revision required. Retrieved from http://www.acya.org.nz/?t=53 [Access date: 15th January 2013]

Ludbrook, R., \& Else, A. (2012, August). Adoption News and Views. The Department of Internal Affairs: Te Tari Taiwhenua. Retrieved from http://adoptionaction.co.nz/wp-content/uploads/ 2013/01/ANV-12.2.pdf [Access date: 12th October 2012]

March, K. (1995). Perception of adoption as social stigma: Motivation for search and reunion. Journal of Marriage and the Family, 57, 653-660. Retrieved from http://au.wiley.com/WileyCDA/ WileyTitle/productCd-JOMF.html

McAdams, D. P. (1993). The stories we live by: Personal myths and the making of the self. New York, NY: William Morrow. 
McRae, K. O., \& Nikora, L. W. (2006). Whangai: Remembering, understanding and experiencing. MAI Review, 1(Intern Research Report 7), 1-18. Retrieved from http://www.review.mai.ac.nz/index.php/MR/article/view/16/16 [Access date: 21st March 2014]

Murphy, K., Quartly, M., \& Cuthbert, D. (2009). 'In the best interests of the child': Mapping the (re) emergence of pro-adoption politics in contemporary Australia. The Australian Journal of Politics and History, 55(2), 201-218.

News. (2012). Adoption reform is not a big issue, says Key. Retrieved from http://www.3news.co.nz/ Adoption-reform-is-not-a-big-issue-says-Key/tabid/1607/articleID/262190/Default.aspx [Access date: 27th July 2012]

Nikora, L. W., Awekotuku, N. T., \& Tamanui, V. (2013). Home and the spirit in the Maori world. Paper presented at the He Manawa Whenua Indigenous Research Conference, 30 June-3 July 2013. Hamilton, New Zealand.

One News. (2012). 'Shamed' mothers may not get official apology. Retrieved from http://tvnz.co.nz/ national-news/victims-forced-adoption-demand-apology-4749319 [Access date: 1st May 2012]

Polkinghorne, D. E. (2005). Language and meaning: Data collection in qualitative research. Journal of Counseling Psychology, 52, 137-145. doi: 10.1037/0022-0167.52.2.137

Riessman, C. K. (2008). Narrative methods for the human sciences. Thousand Oaks, CA: Sage.

Sawicki, J. (1999). Disciplining mothers: Feminism and the new reproductive technologies. In J. Price, \& M. Shildrick (Eds.), Feminist theory and the body: A reader (pp. 190-202). New York, NY: Routledge.

Simmonds, J. (2000). The adoption narrative: Stories that we tell and those that we can't. In A. Treacher, \& I. Katz (Eds.), The dynamics of adoption: Social and personal perspectives (pp. 27-42). London, England: Jessica Kingsley.

The Department of Internal Affairs: Te Tari Taiwhenua. (2014). Marriage Amendment Act Questions and answers. Retrieved from http://www.dia.govt.nz/diawebsite.nsf/wpg_URL/ Services-Births-Deaths-and-Marriages-Marriage-Amendment-Act-Questions-and-Answers? OpenDocument [Access date: 21st March 2014]

Triseliotis, J. (1973). In search of origins: The experiences of adopted people. London, England: Routledge \& Kegan Paul.

Triseliotis, J., Shireman, J., \& Hundleby, M. (1997). Adoption: Theory policy and practice. London, England: Cassell.

Ussher, J. M. (1997). Toward a material discursive analysis of madness, sexuality and reproduction. In J. M. Ussher (Ed.), In body talk: The material and discursive regulation of sexuality, madness and reproduction (pp. 1-9). New York, NY: Routledge.

Ussher, J. M. (2010). Are we medicalizing women's misery? A critical review of women's higher rates of reported depression. Feminism and Psychology, 20, 9-34.

Van Doren, D. H. (1916). Rights of illegitimate children under modern statutes. Columbia Law Review, 16, 698-701.

Wegar, K. (2000). Adoption, family ideology, and social stigma: Bias in community attitudes, adoption research, and practice. Family Relations, 49, 363-370. doi: 10.1111/j.1741-3729.2000.00363.x 
Copyright of Journal of Community \& Applied Social Psychology is the property of John Wiley \& Sons, Inc. and its content may not be copied or emailed to multiple sites or posted to a listserv without the copyright holder's express written permission. However, users may print, download, or email articles for individual use. 